\title{
EVALUATION OF IN VITRO ANTIDIABETIC AND ANTIOXIDANT POTENTIAL OF BARLERIA CRISTATA LEAVES EXTRACTS
}

\section{SAKTHIVEL VASANTH ${ }^{1,2 *}$, GIRIDHARAN BUPESH ${ }^{1 *}$, THARUMASIVAM SIVA VIJAYAKUMAR ${ }^{3}$, VELLINGIRI BALACHANDAR ${ }^{4}$, DURAI RAJAN GUNASEKARAN ${ }^{1}$}

\begin{abstract}
${ }^{1}$ R and D Wing, Central Research Laboratory, Sree Balaji Medical College and Hospital, Chennai, Tamil Nadu, India. ${ }^{2}$ Department of Biochemistry, Annai Violet Arts and Science College, Chennai, Tamil Nadu, India. ${ }^{3}$ Department of Biotechnology, Srimad Andavan College of Arts and Science, Tiruchirappalli, Tamil Nadu, India. ${ }^{4}$ Department of Human Genetics and Molecular Biology, Bharathiar University, Coimbatore, Tamil Nadu, India. Email: sakthivel.vasanth@gmail.com
\end{abstract}

Received: 02 December 2017, Revised and Accepted: 10 January 2018

ABSTRACT

Objectives: The objectives of the study were to study the in vitro antidiabetic and antioxidant activity of Barleria cristata leaves extracts.

Methods: Ethanol extract and petroleum ether extract of leaf and root of B. cristata were tested for their antidiabetic activity. The in vitro antidiabetic activity from $\alpha$-amylase, $\alpha$-glucosidase, and antioxidant activity was used to assess the potential activity of the fractions.

Results: Our attempt results suggest that ethanol and the petroleum ether leaf extract from $B$. cristata show signs of dose-dependent increases to inhibitory activity on $\alpha$-amylase, $\alpha$-glucosidase enzymes, and antioxidant activity when compared with control. Ethanolic leaves to extract produced maximum in vitro antidiabetic effect and antioxidant activity when compared to petroleum ether extract.

Conclusion: The ethanol leaf extract from B. cristata may be used in managing of blood glucose in a medical condition like diabetes.

Keywords: Barleria cristata, Ethanol extract, Petroleum ether extract, Antidiabetic activity, Antioxidant activity, In vitro study.

(C) 2018 The Authors. Published by Innovare Academic Sciences Pvt Ltd. This is an open access article under the CC BY license (http://creativecommons. org/licenses/by/4. 0/) DOI: http://dx.doi.org/10.22159/ajpcr.2018.v11i4.24069

\section{INTRODUCTION}

Diabetes mellitus is a metabolic defect primarily characterized by a loss of glucose homeostasis by a disorder of carbohydrate, fat, and protein metabolism, follow-on from defects in the secretion of insulin or action of insulin, or both [1]. Diabetes mellitus is characterized by hypoglycemia, lipidemia, and oxidative stress affected by many individuals to longstanding complications. In current lots of drugs available to manage and treat diabetic patients, but a total improvement on diabetes may not possible. Remedy for diabetes treatments is not always adequate in maintaining normal levels of blood glucose and avoiding late-stage diabetic consequences [2]. A huge number of medicinal plants are used in the management of diabetes. Medicinal plants have curative property due to the presence of various chemical substances of different composition, secondary metabolites which are found in one or more parts of these plants. The antidiabetic drugs at present clinical use and their similar mechanism of action herbal components are chosen mainly due to lesser side effects and low cost [3].

Barleria cristata is an ornamental perennial shrub belonging to Acanthaceae family. It has been reported on a variety of pharmacological activities such as antimicrobial, hypoglycemic, anti-inflammatory, and hepatoprotective [4,5] an additional shrub of the same family. Barleria prionitis has been more widely researched with documented medicinal properties of the whole plant, leaves, and roots against, e.g. diabetes and respiratory diseases [6]. Inhibition of alpha-amylase and alphaglucosidase enzymes can be an essential approach in the management of postprandial blood glucose level in Type 2 diabetes [7]. Thus, the aim of the present study is to investigate the in vitro antidiabetes, antioxidant, and phytochemical property activities of leaf extracts of B. cristata.

\section{METHODS}

Collection of plant material

Healthy and fresh leaves of Barleria cristata Linn used for the study were obtained from Kurumberi, Vellore district, Tamil Nadu, India. The plant was authenticated by Prof. P. Jayaraman, PARC, Chennai. The voucher specimen was given the No.PARC/2016/3326/1. The fresh leaves were washed with running tap water, shadow dried and powdered.

\section{Preparation of leaves extract}

The leaves of B. cristata L. Was Shado dried and powdered well using a mixer and stored in an airtight container. The leaves powdered (100 g) were taken and subjected to successive solvent extraction (500 ml) with ethanol and petroleum ether. The plant extracts were concentrated and stored in an airtight vial for further studies.

\section{Phytochemical screening}

For preliminary phytochemical analysis, the freshly prepared crude with ethanol and petroleum ether extracts of the leaves were tested for the presence or absence of phytoconstituents such as reducing sugar, tannins, flavonoids, steroids, and alkaloids using standard phytochemical procedures [8].

\section{In vitro antidiabetic studies}

Inhibition of alpha-amylase enzyme

The inhibition alpha-amylase enzyme was determined by Malik and Singh [9]. Briefly, the total assay mixture containing $200 \mu \mathrm{l}$ of sodium phosphate buffers $(0.02 \mathrm{M}), 20 \mu \mathrm{l}$ of enzyme, and the plant extracts from the range of 20-100 $\mu \mathrm{l}$ were incubated for $10 \mathrm{~min}$ at room temperature followed by the addition of $200 \mu \mathrm{l}$ of $1 \%$ starch in all the test tubes. Both control and plant extracts were added with starch solution and left to react with an alpha-amylase solution to alkaline environment at $25^{\circ} \mathrm{C}$. The changes in the reaction were measured more than $3 \mathrm{~min}$. The production of maltose was quantified at $540 \mathrm{~nm}$

\section{Inhibition of alpha-glucosidase enzyme}

The inhibition of alpha-glucosidase enzyme activity was determined [10]. Incubating a solution to starch substrate $(2 \% \mathrm{w} / \mathrm{v}$ maltose) $1 \mathrm{ml}$ with $0.2 \mathrm{M}$ Tris buffer $\mathrm{pH} 8.0$ and different concentrations (20-100 $\mu \mathrm{l})$ of plant extract were added incubation for $5 \mathrm{~min}$ at $37^{\circ} \mathrm{C}$. The reaction 
was initiated by adding $1 \mathrm{ml}$ of alpha-glucosidase enzyme $(1 \mathrm{U} / \mathrm{ml})$ to it followed by incubation for $40 \mathrm{~min}$ at $35^{\circ} \mathrm{C}$. Then, the reaction was terminated by the addition of $2 \mathrm{ml}$ of $6 \mathrm{~N} \mathrm{HCl}$. Then, the color development was measured at $540 \mathrm{~nm}$

\section{Antioxidant activity}

1,1-Diphenyl-2-picrylhydrazyl (DPPH) free radical scavenging activity Different concentrations of B. cristata leaf extract (20-100 $\mu \mathrm{g}$ ) were taken $(0.4 \mathrm{ml})$ and mix with $1.0 \mathrm{ml}$ of $0.2 \mathrm{~mm}$ DPPH solution, resulting in the absolute concentration of DPPH being $0.1 \mathrm{~mm}$. The mixture was shaken well and left to place for $30 \mathrm{~min}$, and the absorbance was measured at $517 \mathrm{~nm}$ [11]. The DPPH free radical scavenging activity was compared with butylated hydroxytoluene (BHT).

\section{Ferric reducing antioxidant power (FRAP)}

The FRAP was determined according to the method of Oyaizu [12]. Briefly, various concentrations of extracts $(20-100 \mu \mathrm{g})$ in $1 \mathrm{ml}$ of distilled water were mixed with 2.5 of $\mathrm{ml} 0.2 \mathrm{M}$ phosphate buffer (pH 6.6) and $1 \%$ potassium ferricyanide $(2.5 \mathrm{ml})$. The mixture was incubated at $50^{\circ} \mathrm{C}$ for $25 \mathrm{~min}$. An aliquot $(2.5 \mathrm{ml})$ of trichloroacetic acid $(10 \%)$ was added to the mixture; the mixture was then centrifuged at 3000 revolutions per minute for $10 \mathrm{~min}$. The supernatant $(2.5 \mathrm{ml})$ was mixed with distilled water $(2.5 \mathrm{ml})$ and $\mathrm{FeCl} 3(0.5 \mathrm{ml}$ and $0.1 \%)$ and the absorbance was measured at $700 \mathrm{~nm}$. Ascorbic acid was used as the reference. The increased absorbance of the reaction mixture indicated increased reducing power.

\section{Statistical analysis}

The values were expressed as mean \pm standard error of the mean $(n=5)$. Differences between groups were assessed by one-way analysis of variance using the Statistical Packages for the Social Sciences Software package for Windows (version 16.0). Post-hoc testing was carried out for intergroup comparisons using the least significant difference test and the values of $\mathrm{p}<0.05$ were considered as statistically significant.

\section{RESULT}

\section{Phytochemical screening}

The preliminary phytochemical screening result is shown in Table 1, which represent that the alkaloids, carbohydrates, glycosides, steroids, flavonoid, saponins, and phenolic compounds are present in different extracts of the leaf. The amino acids and proteins were not present in extracts from B. cristata. The percentage yield of ethanol and petroleum ether extracts of B. cristata leaves $10 \%$ and $6 \%$. In that maximum yield was found in ethanol extract. One of these secondary metabolites, individually or in combine with others might be responsible for the antidiabetic action of the plant.

\section{In vitro alpha-amylase inhibitory activity}

The human digestive system contains lots of enzymes that help in the digestion of food. $\alpha$-amylase catalyzes the breakdown of polysaccharide into simple sugar and only monosaccharide form of food can be able to absorb in the stomach. B. cristata leave extracts (ethanol and petroleum ether) were at the shows the dose-dependent increases from percentage inhibitory activity against the alpha-amylase enzyme. The ethanol extract from $B$. cristata showed a maximum percentage inhibition $67 \%$ at a concentration of $100 \mu \mathrm{l}$ while its petroleum ether extract shows $61 \%$ (Table 2).

\section{In vitro alpha-glucosidase inhibitory activity}

The $B$. cristata leave extracts revealed a significant inhibitory action of alpha-glucosidase enzyme. The percentage inhibition at 20-100 $\mu \mathrm{l}$ concentrations of $B$. cristata leave showed a dose-dependent increase in percentage inhibition. The percentage inhibition varied from $47.7 \%$ to $15.2 \%$ for the highest concentration on the lowest concentration (Table 3 ).

\section{Antioxidant activity}

Scavenging activity of with ethanol and petroleum ether extracts was studied against DPPH radicals. All the samples were analyzed in triplicate. The antioxidant activity of the extracts was estimated by DPPH free radical scavenging, using BHT as controls was shown in Table 4. Maximum activity was shown by ethanol leaf extract (76.01) and was observed at $100 \mu \mathrm{g} / \mathrm{ml}$ concentrations followed by a petroleum ether leaf extract (70.57) again at $100 \mu \mathrm{l}$. As the concentration of all the extracts increases, the activity also increases. Minimum activity was shown by petroleum ether leaf extract (21.40) from $10 \mu \mathrm{l}$ concentrations. A significant $(\mathrm{p}<0.05)$ dose-response relationship is found in the DPPH radical scavenging activity in B. cristata extract.

Table 5 reveals that a significant $(\mathrm{p}<0.05)$ dose-response relationship is found in the ferric reducing power activity in B. cristata extract. The result clearly indicates that the reducing power of the B. cristata extract increased to increasing the concentration and is comparable with the standard ascorbic acid; hence, B. cristata is having the antioxidant activity.

\section{DISCUSSION}

Diabetes mellitus is a metabolic disorder with growing incidence of the world. Insulin is a key role in control of glucose homeostasis. Shortage of insulin affects carbohydrate, fat, and protein metabolism [13]. Management of diabetes without side effects is still challenging about the society. It was planned that inhibition of the activity of such alpha-amylase and alpha-glucosidase would postpone in degradation of carbohydrate, which would turn in the absorption of glucose was decreased, as an affect the decline in postprandial blood glucose level high [14].

Table 1: Preliminary phytochemical screening of Barleria

\begin{tabular}{llll}
\hline \multicolumn{2}{l}{ CRISTATA } & & \\
\hline S. No & $\begin{array}{l}\text { Phytochemical } \\
\text { constituents }\end{array}$ & $\begin{array}{l}\text { Ethanol } \\
\text { extract }\end{array}$ & $\begin{array}{l}\text { Petroleum } \\
\text { ether extract }\end{array}$ \\
\hline 1 & Alkaloids & ++ & ++ \\
2 & Carbohydrates & ++ & ++ \\
3 & Flavonoids & ++ & +++ \\
4 & Saponin & ++ & ++ \\
5 & Steroids & + & + \\
6 & Tannins & + & + \\
7 & Phenolic compounds & ++ & ++ \\
8 & Amino acids & - & - \\
9 & Proteins & - & - \\
\hline$+++=$ High, ++=moderate, +=present, -=absent &
\end{tabular}

Table 2: In vitro antidiabetic activity of alpha-amylase

\begin{tabular}{|c|c|c|c|}
\hline \multirow[t]{2}{*}{ S. No } & \multirow{2}{*}{$\begin{array}{l}\text { Concentration of } \\
\text { sample }(\mu \mathrm{l})\end{array}$} & \multicolumn{2}{|c|}{$\%$ of inhibition } \\
\hline & & $\begin{array}{l}\text { Ethanol } \\
\text { extract }\end{array}$ & $\begin{array}{l}\text { Petroleum ether } \\
\text { extract }\end{array}$ \\
\hline 1 & 20 & 38.3 & 33.8 \\
\hline 2 & 40 & 45.4 & 40.6 \\
\hline 3 & 60 & 53.7 & 49.0 \\
\hline 4 & 80 & 60.9 & 55.2 \\
\hline 5 & 100 & 67.1 & 61.9 \\
\hline
\end{tabular}

Values are given in mean \pm SEM for $n=3$. SEM: Standard error of the mean

Table 3: In vitro antidiabetic activity of alpha-glucosidase

\begin{tabular}{|c|c|c|c|}
\hline \multirow[t]{2}{*}{ S. No } & \multirow{2}{*}{$\begin{array}{l}\text { Concentration of } \\
\text { sample }(\mu \mathrm{l})\end{array}$} & \multicolumn{2}{|c|}{$\%$ of inhibition } \\
\hline & & $\begin{array}{l}\text { Ethanol } \\
\text { extract }\end{array}$ & $\begin{array}{l}\text { Petroleum ether } \\
\text { extract }\end{array}$ \\
\hline 1 & 20 & 18.3 & 15.2 \\
\hline 2 & 40 & 26.7 & 22.1 \\
\hline 3 & 60 & 32.3 & 29.4 \\
\hline 4 & 80 & 40.5 & 36.8 \\
\hline 5 & 100 & 47.7 & 44.1 \\
\hline
\end{tabular}


Table 4: DPPH free radical scavenging activity of $B$. cristata extracts

\begin{tabular}{|c|c|c|c|c|}
\hline \multirow[t]{2}{*}{ S. No } & \multirow{2}{*}{$\begin{array}{l}\text { Concentration } \\
\text { of sample }(\mu l)\end{array}$} & \multicolumn{2}{|c|}{$\%$ of inhibition } & \multirow{2}{*}{$\begin{array}{l}\text { Control } \\
\% \mathrm{BHT}\end{array}$} \\
\hline & & $\begin{array}{l}\text { Ethanol } \\
\text { extract }\end{array}$ & $\begin{array}{l}\text { Petroleum } \\
\text { ether extract }\end{array}$ & \\
\hline 1 & 20 & 26.4 & 21.5 & \multirow{5}{*}{86.4} \\
\hline 2 & 40 & 41.7 & 37.3 & \\
\hline 3 & 60 & 53.9 & 48.8 & \\
\hline 4 & 80 & 68.1 & 63.1 & \\
\hline 5 & 100 & 76.4 & 70.5 & \\
\hline
\end{tabular}

Values are given in mean \pm SEM for $\mathrm{n}=3$. SEM: Standard error of the mean, DPPH: 1,1-Diphenyl-2-picrylhydrazyl, B. cristata: Barleria cristata, BHT: Butylated hydroxytoluene

Table 5: FRAP activity of $B$. cristata extracts

\begin{tabular}{lllll}
\hline S. No & $\begin{array}{l}\text { Concentration } \\
\text { of sample }(\mu \mathrm{l})\end{array}$ & $\%$ of inhibition & $\begin{array}{l}\text { Control \% } \\
\text { ascorbic } \\
\text { acid }\end{array}$ \\
\cline { 3 - 5 } & & $\begin{array}{l}\text { Ethanol } \\
\text { extract }\end{array}$ & $\begin{array}{l}\text { Petroleum ether } \\
\text { extract }\end{array}$ \\
\hline 1 & 20 & 0.037 & 0.24 & 0.247 \\
2 & 40 & 0.054 & 0.041 & \\
3 & 60 & 0.072 & 0.057 & \\
4 & 80 & 0.097 & 0.083 & \\
5 & 100 & 0.147 & 0.126 & \\
\hline
\end{tabular}

Values are given in mean \pm SEM for $n=3$. SEM: Standard error of the mean, FRAP: Ferric reducing antioxidant power, B. cristata: Barleria cristata

In the present study has been conducted to evaluate the preliminary phytochemical investigation and the potential for ethanol and petroleum ether extract from $B$. cristata leaf in inhibiting alpha-glucosidase and alpha-amylase.

The ethanol and petroleum ether extracts from B. cristata were tested for phytochemical constituents such as flavonoid, glycosides, carbohydrates, steroids, proteins, and amino acids. Understanding the knowledge of chemical constituents of plants helps to screen for biological activities. Phytochemistry of the extracts of B. cristata leaves reveals that they contain flavonoid, phenol, and tannins as secondary metabolites which confirm that the extracts of $B$. cristata leaves have a broad range of biological activities such as anti-inflammatory, antioxidant, anti-arthritic, antidiabetic, and membrane stabilizing activities. This study is in evidence for previous studies [15]. Presence of secondary metabolites indicative of the curative potential for the plant as all the chief class of compounds is identified with their anticancer, anti-inflammatory, and antirheumatic properties [16-18].

The current result reveals that B. cristata capably inhibits both alpha-amylase and alpha-glucosidase enzymes in vitro in a dosedependent mode. The ethanol extracts from B. cristata seeds showed a dose-dependent inhibitory effect of alpha-amylase activity of oral administering, produced a significant decrease in the blood glucose level in the model of alloxan-induced diabetes in rats [19]. The antidiabetic action of $B$. cristata can also be recognized to the alpha-amylase and alpha-glucosidase inhibitory action. In added to this study is necessary to elucidate whether $B$. cristata contained antidiabetic prospective by in vivo for validating the established claim on the plant. Dheer and Bhatnagar [20] carried out an antidiabetic activity of alcoholic extract from $B$. prionitis in rats exhibited significantly higher effect.

In this present study, we evaluated the in vitro antioxidant activity of ethanol and petroleum ether extract of $B$. cristata by various assays such as DPPH and FRAP. For DPPH activity, it shows that the DPPH free radical scavenging capacity of ethanol extracts from $B$. cristata has proportionally increased from the increase in the concentration of $B$. cristata plant extract. Ferric reducing the ability of plasma assay shows that ethanol extracts from B. cristata inhibited more ferric reducing activity compared to petroleum ether extract. Pathy et al. [21] reported that in vitro antioxidant activities of methanol and acetone extracts of B. cristata leaf and bark showed significant antioxidant activities. The same results were observed in petroleum ether and ethanol extracts of B. prionitis leaves [22]. Arumugam reported that ethyl acetate fraction of Barleria noctiflora showed the highest antidiabetic activity [23]

\section{CONCLUSION}

The present study concluded that ethanol and petroleum ether extract of $B$. cristata leaves not only possess remarkable inhibitory potential against $\alpha$-glucosidase and $\alpha$-amylase but also exhibited excellent in scavenging activity on the DPPH and FRAP activity. The results of this study direct further study to assess the therapeutic potentialities of $B$. cristata L. in vivo in animal models.

\section{ACKNOWLEDGMENTS}

The authors are thankful to Sree Balaji Medical College and Hospital, Chrompet, Chennai-600044, Tamil Nadu, India, and Annai Violet Arts and Science College, Ambattur, Chennai-600053, Tamil Nadu, India, for the facilities to carry out the research. The authors wish to record their thanks to Prof. P. Jayaraman, Director, Retd. Professor, Presidency College, Chennai, for authenticated of plant material.

\section{AUTHORS CONTRIBUTION}

Sakthivel Vasanth: Designed the experimental study and carried out analysis. Further, the manuscript was drafted. Giridharan Bupesh: Provided suggestions during the work. Tharumasivam Siva vijayakumar: Provided suggestions during the Work. Vellingiri Balachandar: Provided guidance and suggestions during the work and reviewed the article draft. Durai rajan Gunasekaran: Provided guidance and suggestions during the work and reviewed the article draft.

\section{CONFLICTS OF INTEREST}

Declared none.

\section{REFERENCES}

1. Barcelo A, Rajpathak S. Incidence and prevalence of diabetes mellitus in the Americas. Pan Am J Public Health 2010;10:300-8.

2. Prabhakar PK, Doble M. Mechanism of action of natural products used in the treatment of diabetes mellitus. Chin J Integr Med 2011;17:563- 74.

3. Aghajanyan A, Movsisyan Z, Trchounian A. Antihyperglycemic and antihyperlipidemic activity of hydroponic stevia rebaudiana aqueous extract in hyperglycemia induced by immobilization stress in rabbits. BioMed Res Int 2017; Article ID: 9251358, 6.

4. Gambhire M, Juvekar M, Juvekar A, Wankhede S, Sakat S. Evaluation of anti-inflammatory and radical scavenging activity of an aqueous extract of Barleria cristata leaves. Planta Med 2009;75:166-9.

5. Amutha K, Doss VA. In vitro antioxidant activity of ethanolic extract of Barleria cristata L. leaves. Res J Pharm Phytochem 2009;1:209-12.

6. Kumar U, Ahmed F, Khanojia P, Kukreja K, Kumari S, Bhat RA. Exploration of antioxidant and antibacterial activity of Barleria prionitis Linn. Int J Curr Microbiol App Sci 2013;2:585-91.

7. Ali S, Stone MA, Peters JL, Davies MJ, Khunti K. The prevalence of co-morbid depression in adults with Type 2 diabetes: A systematic review and meta-analysis. Diabetic Med 2006;23:1165-73.

8. Evans WC, Evans T. Pharmacognosy. $5^{\text {th }}$ ed. London: Cambridge University Press; 2003. p. 336-93.

9. Malik CP, Singh MB. Plant Enzymology and Histoenzymology. New Delhi: Kalyani Publishers; 1980. p. 278.

10. Krishnaveni S, Theymoli B, Sadasivam S. Phenol sulphuric acid method. Food Chem 1984;15:229.

11. Bruce A, Tommasi LD, Bari C, Pizza M, Morelli P. Antioxidant principles from Bauhinia terapotensis. J Natl Prod 2001;64:892-5.

12. Oyaizu M. Studies on products of browning reactions: Antioxidant activities of products of browning reaction prepared from Glucosamine. J Nutrit 1986;44:307-15.

13. Gandhi GR, Sasikumar P. The anti-diabetic effect of Merremia 
emarginata Burm in streptozotocin induced diabetic rats. Asian Pace J Trop Biomed 2012;2:281-6.

14. Chiasson JL, Rabasa-Lhoret R. Prevention of Type 2 diabetes: Insulin resistance and beta-cell function. Diabetes 2004;53 Suppl 3:S34-8.

15. Amoo SO, Ndhlala AR, Finnie JR, Staden JV. Antifungal, acetylcholinesterase inhibition, antioxidant and phytochemical properties of three Barleria species. South Afr J Bot 2011;77:435-45.

16. Jyoti KS, Shesgiri M. In-vitro activity of saponins of Bauhinia purpurea, Madhuca longifolia, Celastrus paniculatus and Semecarpus anacardium on selected oral pathogens. J Dent (Tehran) 2012;9:216-23.

17. Kumar S, Pandey AK. Chemistry of biological activities of flavonoids: An overview. Sci World J 2013;162750:1-16.

18. Atif M, Rahman SA, Ahmed MI, Mahmood SB, Azharuddin M. Anticataract potential of Barleria prionitis: In vivo study. Int J Pharm Pharm Sci 2014;72:100-5.
19. Sing PR, Rajasree H, Sankar C. Screening for anti-diabetic activity of the ethanolic extract of Barleria cristata seeds. Int J Pharm Life Sci 2012;3:2044-7.

20. Dheer R, Bhatnagar P. A study of the anti-diabetic activity of Barleria prionitis Linn. Indian J Pharm 2010;42:70-3.

21. Pathy M, Sharma T, Bhatnagar S. Barleria cristata: A comparative analysis of phytochemical, cytotoxic and antioxidant activities of leaf and bark extracts. EJPMR 2015;2:586-93.

22. Aiswarya T, Ravikumar R. A comparitive study of phytochemical analysis, antibacterial. Activity and antioxidant activity of Barleria prionitis leaves extract of petroleum ether and ethanol extract. Int J ChemTech Res 2014;6:3025-33.

23. Suresh A, Senthilkumar N. Hypoglycemic effects of barleria noctiflora fractions on high fat fed with low dose streptozotocin induced Type-2 diabetes in rats. Int J Pharm Pharm Sci 2016;8:193-200. 